\title{
Emergence of Phyllochron of 3 Rice Varieties in Different time of Land Flooding in System of Rice Intensification (SRI)
}

\author{
Indra Dwipa, Nalwida Rozen Musliar Kasim \\ Department of Agronomy, Faculty of Agriculture, Andalas University, Indonesia \\ Email: 1965indradwipa@gmail.com
}

\begin{abstract}
System of rice intensification (SRI) is a method of rice cultivation which has proven to increase the rice yield if comparing to the conventional method. The research aimed to study the influence of flooding of land to phyllochron emergence and tiller of rice plant. The research was conducted in farmer field in Koto Tangah, Padang from May-June 2018. Randomized block design in split-plot was used in this research. The main plot was the inundation time before planting in 7, 14, 21 and 28 days. Three replications were used in this research. The subplot was the three rice varieties, Pandan Wangi, PB 42 and Kuranji 012. The result showed that variety $P B 042$ and Kuranji 012 in 14 days of inundation were the best variety with the amounts of tillers were 40.
\end{abstract}

Keywords-Flooding, phyllochron, SRI.

\section{INTRODUCTION}

Rice (Oryza sativa L.) is a dietary staple foods and one of the most important cereal crops, especially for people in Asia, but the consumption outside Asia has increased, recently (Orthoefer, 2005). It provides the bulk of daily calories for many companion animals and humans (Ryan, 2011).

Efforts to increase rice production have been carried out in various ways, but Indonesia still imports rice from the other country such as Thailand and Vietnam (Mariyono 2014). Even though the area under rice cultivation is large; the productivity is low due to various interaction factors. The imbalance usage of fertilizers is one of the main factors responsible for the low productivity and also the continuous use of inorganic fertilizers resulted in declining of soil fertility (Aaasif et al. 2018). For solving this problem, one way can be used is System of Rice Intensification (SRI). System of rice intensification (SRI) is a rice cultivation method that can provide higher yields with fewer inputs than conventional methods including irrigation water (Veeramani et al. 2012). Uphoff et al., (2002) stated that SRI can increase yields up to two times or more, because of land and water management, with wider spacing $(25 \mathrm{~cm} \times 25 \mathrm{~cm})$, seedlings planted one point per planting point, seedling age seeding is shorter (715 days), and the soil is moist until hair cracks during the vegetative phase. This situation makes microclimate better around plants. Rozen et al. (2011) stated that the SRI method of rice cultivation can provide yields of dry grain harvested by 10 tons/ha, while rice production in West Sumatra has only reached 4.6 tons/ ha.

The reason why the SRI method can improve yields is because tillers are formed earlier and multiply. In this method, phyllocron is formed up to 12 times. Phyllochron is a phytomer circuit that is formed for 3-5 days after planting depending on temperature (Uphoff et al, 2002). Veeramani et al. (2012) added that phyllocron is influenced by temperature, seed age, and nursery method. Amount of water requirement for growth and development of rice plant is still unknown yet. This condition causes the farmers give the excess water in rice field. The excess water that given to rice field causes the waste of water. The way to avoid the waste of this water is to arrange the water height in land. Uphoff (2002) stated that based on System of Rice Intensification (SRI) method, the minimum height such us 1-2 cm could save the water use and without the reducing of yield. Gani (2007) reported that the height of water $2-3 \mathrm{~cm}$ could increase the grain yield twice than 7-10 cm. Suhartatik et al. (2011) also reported that the 2 days of time interval influenced 98,85 of grill dry grain yield and production of dry grain yield per ha. Furthermore, Zani (2008) reported that the productivity of land in flooding treatment in $5 \mathrm{~cm}$ could save water up to $21 \%$. The research aimed to study the influence of flooding to phyllochron emergence and tiller of rice plant.

\section{MATERIAL AND METHODS}

Place and Time

The research was conducted in farmer's rice field in Koto Tangah, Padang from May-June 2018.

Method

Randomized block design in split-plot was used in this research. The main plot was the inundation time before planting in 7, 14, 21 and 28 days. Three replications were 
used in this research. The subplot was the three rice varieties, Pandan Wangi, PB 42 and 012 Kuranji. Observation data were analyzed by variance and if $\mathrm{F}$ result was higher than $\mathrm{F}$ table then continued with DNMRT further test at $5 \%$.

\section{RESULT AND DISCUSSION}

Development of Phyllochron

The result showed that variety Kuranji 012 and PB 42 produced the best tiller (40) (Figure 1 and 2). The different result occurred in variety Pandan Wangi where the total of tiller was 37 (Figure 3). Based on this result, the flooding of land affected the amount of tiller formed. The weeds can't stand in standing water because they don't have a morphological structure to support it. Inundation affected nitrogen availability in the soil. The longer of inundation, the absorption efficiency of element $\mathrm{N}$ decreases. Flooding also can change chemical properties, microbiology and nutrient availability in the ground (Rachmawati and Retnaningrum 2013).

The phyllochron was used to characterize the growth dynamic of cereal plants. On variety Kuranji 012, tiller was formed from the $2^{\text {nd }}$ phyllochron. There was an exponential increasing in formation of tiller from $7^{\text {th }}$ to $12^{\text {th }}$ phyllochron (Table 1). For variety PB 042, the tiller was formed from $2^{\text {nd }}$ phyllochron (Table 2). An exponential increasing occurred from $7^{\text {th }}$ to $12^{\text {th }}$ phlylochron in formatting of tiller. The tillering of variety Pandan Wangi was similar to both varieties. ). An exponential increasing occurred from $7^{\text {th }}$ to $12^{\text {th }}$ phlylochron in formatting of tiller (Table 3). In SRI method, the seedlings were transplanted early so that 12 phyllochron can be completed and the formation of tiller is exponential. Barkelaar (2002) stated that the phyllochron is 5-7 days in rice and affected by temperature. Veeramani et al. (2012) added that the phyyllochron was influenced by temperature, age of seedlings transplanting and nursery method used.

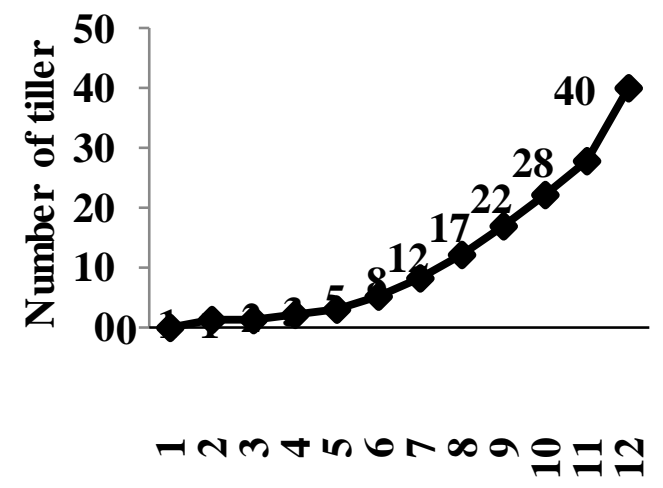

Phyllochron

Fig.1. Number of tiller of variety 012 Kuranji formed in 14 days of inundation

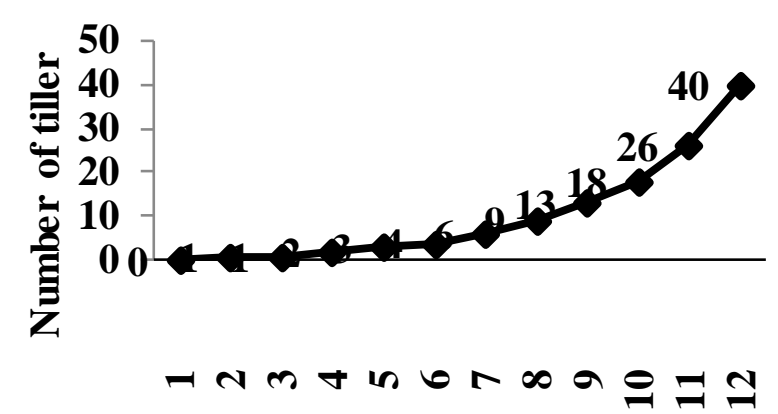

Phyllochron

Fig.2. Number of tiller of variety PB 42 formed in 14 days of inundation

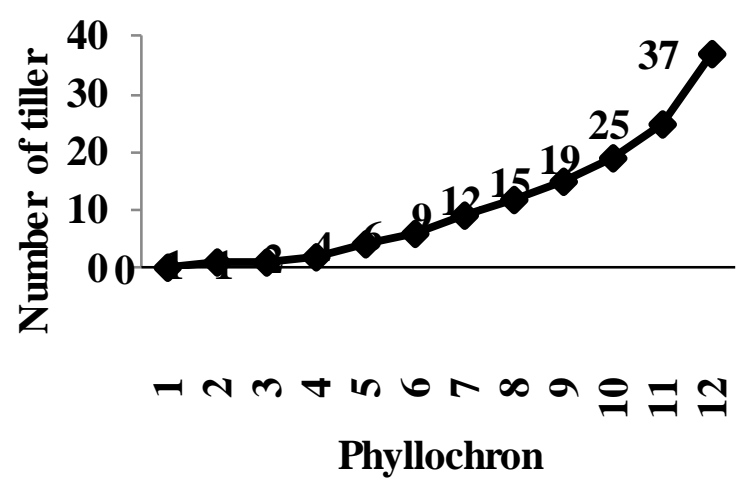

Fig.3. Number of tiller of variety Pandan Wangi formed in 7 days of flooding

SRI method provides a conducive environment for tiller growth during growth phase (Laulanie 1993). According to the phyllochron theory, the chance of forming more tillers will be more if seedlings are transplanted in early phase. These are the main component of SRI method (Laulanie 1993; Barkelaar 2001; Uphoff et al. 2002). On reported that for maximum tillering, the plant has to complete as many phyllochrons as possible during its vegetative phase. Each tiller produces another two phyllochrons later under favorable growing conditions (Singh et al. 2007). When a seedling is transplanted carefully at the initial growth stage, the trauma of root damage caused during uprooting is minimized following a rapid growth with short phyllochrons. 


\begin{tabular}{lccccccccccccc}
\hline Phyllochron stage & $\mathbf{1}$ & $\mathbf{2}$ & $\mathbf{3}$ & $\mathbf{4}$ & $\mathbf{5}$ & $\mathbf{6}$ & $\mathbf{7}$ & $\mathbf{8}$ & $\mathbf{9}$ & $\mathbf{1 0}$ & $\mathbf{1 1}$ & $\mathbf{1 2}$ & Total \\
\hline Main Stalk & & 1 & & & & & & & & & & & 1 \\
First row of tillers & & & & 1 & 1 & 1 & 1 & 1 & 1 & & & & 6 \\
Second row of tiller & & & & & 1 & 1 & 2 & 2 & 2 & 1 & 2 & 11 \\
Third row of tiller & & & & & & & 1 & 1 & 2 & 2 & 3 & 5 & 14 \\
Fourth row of tiller & & & & & & & & & 1 & 2 & 4 & 7 \\
Fifth row of tiller & & & & & & & & & & & & 1 & 1 \\
Total number per & & & & & & & & & & & & & \\
phyllochron & 0 & 1 & 0 & 1 & 1 & 2 & 3 & 4 & 5 & 5 & 6 & 12 & 40 \\
Total & 0 & 1 & 1 & 2 & 3 & 5 & 8 & 12 & 17 & 22 & 28 & 40 & \\
\hline
\end{tabular}

Table 2. Formation of tiller of variety PB 042 in 14 days of inundation

\begin{tabular}{|c|c|c|c|c|c|c|c|c|c|c|c|c|c|}
\hline Phyllochron stage & 1 & 2 & 3 & 4 & 5 & 6 & 7 & 8 & 9 & 10 & 11 & 12 & Total \\
\hline Main Stalk & & 1 & & & & & & & & & & & 1 \\
\hline First row of tillers & & & & 1 & 1 & 1 & 1 & 1 & 1 & & & & 6 \\
\hline Second row of tiller & & & & & & & 1 & 1 & 2 & 2 & 1 & 2 & 9 \\
\hline Third row of tiller & & & & & & & & 1 & 1 & 2 & 4 & 7 & 15 \\
\hline Fourth row of tiller & & & & & & & & & & 1 & 3 & 4 & 8 \\
\hline Fifth row of tiller & & & & & & & & & & & & 1 & 1 \\
\hline Total number per & & & & & & & & & & & & & \\
\hline phyllochron & 0 & 1 & 0 & 1 & 1 & 1 & 2 & 3 & 4 & 5 & 8 & 14 & 40 \\
\hline Total & 0 & 1 & 1 & 2 & 3 & 4 & 6 & 9 & 13 & 18 & 26 & 40 & \\
\hline
\end{tabular}

Table 3. Formation of tiller of variety Pandan Wangi in 7 days of inundation

\begin{tabular}{|c|c|c|c|c|c|c|c|c|c|c|c|c|c|}
\hline $\begin{array}{l}\text { Phyllochron } \\
\text { stage }\end{array}$ & 1 & 2 & 3 & 4 & 5 & 6 & 7 & 8 & 9 & 10 & 11 & 12 & Total \\
\hline Main Stalk & & 1 & & & & & & & & & & & 1 \\
\hline First row of tillers & & & 0 & 1 & 1 & 1 & 1 & 1 & 1 & & & & 6 \\
\hline Second row of & & & & & & & & & & & & & \\
\hline tiller & & & & & 1 & 1 & 1 & 1 & 2 & 1 & 1 & 2 & 10 \\
\hline Third row of tiller & & & & & & & 1 & 1 & & 2 & 2 & 7 & 13 \\
\hline Fourth row of & & & & & & & & & & & & & \\
\hline tiller & & & & & & & & & & 1 & 2 & 2 & 5 \\
\hline Fifth row of tiller & & & & & & & & & & & 1 & 1 & 2 \\
\hline Total number per & & & & & & & & & & & & & \\
\hline phyllochron & 0 & 1 & 0 & 1 & 2 & 2 & 3 & 3 & 3 & 4 & 6 & 12 & 37 \\
\hline Total & 0 & 1 & 1 & 2 & 4 & 6 & 9 & 12 & 15 & 19 & 25 & 37 & \\
\hline
\end{tabular}

Formation of total of tiller and total of productive tiller

The phyllochron influences the tiller of rice plant.

The result showed that the different of number of tiller of 3 varieties occurred in the 21 of flooding (Table 4). Generally, length of flooding didn't affect the total of tiller. The number of tiller is influenced by genetic factor
(Tien et al. 2017). Badshah et al. (2014) stated that the rice plant enabled to form productive tiller based on total of tiller, but not always due to the formation of tiller also influenced by environment. Wang et al. (2017) stated that the plant will form the productive tiller that reflected by the formed tiller. 
Table 4. Total of tiller of 3 rice varieties in different land time offlooding

\begin{tabular}{|c|c|c|c|}
\hline \multirow[t]{2}{*}{ Flooding time (hari) } & \multicolumn{3}{|c|}{ Varieties } \\
\hline & Pandan Wangi & PB 042 & Kuranji 012 \\
\hline \multirow[t]{2}{*}{7} & $37,67 \mathrm{~A}$ & $35,83 \mathrm{~A}$ & $38,83 \mathrm{~A}$ \\
\hline & $\mathrm{a}$ & $\mathrm{a}$ & $\mathrm{a}$ \\
\hline \multirow[t]{2}{*}{14} & $35,60 \mathrm{~A}$ & $35,90 \mathrm{~A}$ & $37,10 \mathrm{~A}$ \\
\hline & $\mathrm{a}$ & $\mathrm{a}$ & $\mathrm{a}$ \\
\hline \multirow[t]{2}{*}{21} & $30,10 \mathrm{~B}$ & $31,00 \mathrm{AB}$ & $34,50 \mathrm{~A}$ \\
\hline & $\mathrm{a}$ & $\mathrm{a}$ & $\mathrm{a}$ \\
\hline \multirow[t]{2}{*}{28} & $36,50 \mathrm{~A}$ & $37,10 \mathrm{~A}$ & $35,10 \mathrm{~A}$ \\
\hline & $\mathrm{a}$ & $\mathrm{a}$ & $\mathrm{a}$ \\
\hline
\end{tabular}

Notes : the numbers followed capital letters in the same rows and the numbers followed the lowercase in the same column are not different significantly

The cultivation of rice plant ins SRI method affected the total of tiller. In SRI method, the total of seedling that planted is only 1 so that it optimizes the growth of rice tiller. Mondol et al. (2017) explained that the density of plant affected the tiller growth. The contiguous clumps will undergo the competition in absorption of nutrients form soil. Berkelaar (2001) reported that for maximum tillering, the plant has to complete as many phyllochrons as possible during its vegetative phase. Each tiller produces another two phyllochrons later under favorable growing conditions (Singh et al. 2007). When a seedling is transplanted carefully at the initial growth stage, the trauma of root damage caused during uprooting is minimized following a rapid growth with short phyllochrons.

The total of tiller affected the total of productive tiller of rice plant. The result showed that the flooding time in 14 days was the best treatment for total of productive tiller (Table 5). The flooding time didn't affect the total of Kuranji 012 variety tiller. The different of productive tiller for each variety was influenced by genetic factor of each variety. Badshah et al. (2017) stated that the ability of rice plant to form productive tiller was influenced by genetic factor and each variety of rice plant had different genetic. The total of productive tiller represents the total of tiller that produced previously.

Table 5. Total of productive tiller of 3 rice varieties in different land time offlooding

\begin{tabular}{|c|c|c|c|}
\hline \multirow[t]{2}{*}{ Flooding time (days) } & \multicolumn{3}{|c|}{ Varieties } \\
\hline & Pandan Wangi & PB 042 & Kuranji 012 \\
\hline \multirow[t]{2}{*}{7} & $37,67 \mathrm{~A}$ & $35,83 \mathrm{~A}$ & $38,83 \mathrm{~A}$ \\
\hline & $\mathrm{a}$ & $\mathrm{a}$ & $\mathrm{a}$ \\
\hline \multirow[t]{2}{*}{14} & $35,60 \mathrm{~A}$ & $35,90 \mathrm{~A}$ & $37,10 \mathrm{~A}$ \\
\hline & $\mathrm{a}$ & $\mathrm{a}$ & $\mathrm{a}$ \\
\hline \multirow[t]{2}{*}{21} & $30,10 \mathrm{~B}$ & $31,00 \mathrm{AB}$ & $34,50 \mathrm{~A}$ \\
\hline & $\mathrm{a}$ & $\mathrm{a}$ & $\mathrm{a}$ \\
\hline \multirow[t]{2}{*}{28} & $36,50 \mathrm{~A}$ & $37,10 \mathrm{~A}$ & $35,10 \mathrm{~A}$ \\
\hline & $\mathrm{a}$ & $\mathrm{a}$ & a \\
\hline
\end{tabular}

Notes : the numbers followed capital letters in the same rows and the numbers followed the lowercase in the same column are not different significantly

\section{CONCLUSION}

The result showed that variety PB 042 and Kuranji 012 in 14 days of inundation were the best variety with the amounts of tillers were 40 . The variety Kuranji 012 was the best variety for total of tiller and total of productive tiller.

\section{ACKNOWLEDGEMENTS}

Special thanks to Andalas Universuty that has funded this research and all participants that have supported the research. 
REFERENCES

[1] Aasif M, Chinnamani I, Kumar NS, Hemalatha M, Suresh S. (2018). Influence of Integrated Nutrient Management Practices on Yield and Nutrient Uptake of Rice under System of Rice Intensification. International Journal of Advances in Agricultural Science and Technology. 5(7): 10-16

[2] Badshah MA, Tu N, Zou Y, Ibrahim M, Wang K. (2014). Yield and tillering response of super hybrid rice Liangyoupeijiu to tillage and establishmentmethods. Crop Journal. 2 : 79-86

[3] Barkelaar D. (2001). SRI, The system of Rice Intensification: Less Can Be More. ECHO Development Notes.

[4] Laulanie, H. (1993). Le systeme de riziculture intensive malgache. Tropicultura, II: 110-114.

[5] Mariyono J. (2014). Rice production in Indonesia: policy and performance. Asia Pacific Journal of Public Administration. 36:2, 123-134

[6] Mondol AP, Biswas PK, Islam S. (2017). Performance of System of Rice Intensification With Conventional Method of Rice Cultivation. Bangladesh Agronomy. 20(2): 75-80

[7] Orthoefer FT. (2005). Rice Brain Oil. In Bailey's Industrial Oil and Fat Products, Sixth Edition. New York: John Wiley \& Sons, Inc.

[8] Rachmawati D, Retnaningrum E. (2013). Influence of height and length of inundation to rice growth variety Sintanur and population dynamics of non-symbiotic N-fixing rhizobacteria. Bionatura. 15(2): 117-125

[9] Rozen N, Syafrizal, Sabrina. (2011). Increased potential of rice crops through the transfer of SRI technology in Padang. Report of Service to Ibn's Community Program. DP2M Dikti

[10] Ryan EP. (2011). Bioactive food components and health properties of rice bran. Journal of the American veterinary Medical Association. 238: 593 - 600.

[11] Sinha, S.K. and Talati, J. (2007) Productivity Impacts of the System of rice Intensification (SRI): A Case Study in West Bengal, India. Agricultural Water Management. 87: 55-60

[12] Uphoff N, Yang KS, Gypmantasiri P, Prinz K, Kabir H. (2002). The system of rice intensification (SRI) and its relevance for food security and natural resource management in Southeast Asia. International Symposium Sustaining Food Security and Managing Natural Resource in Southeast Asia Challenge for 21 century. January 8-11, 2002.

[13] Veeramani P, Singh RD, Subhrahmaniyan K. (2012). Study of phyllochron - System of Rice Intensification (SRI) technique. Agricultural Science Research Journal. 2(6): 329-334
[14] Wang X, Pang, Wang C, Chen K, Zhu Y, Shen C, Ali J, Xu J, Li Z. 2017. New Candidate Genes Affecting Rice Grain Appearance and Milling Quality Detected by Genome-Wideand Gene-Based Association Analyses. Frontiers in Plants Science. 7: 1-11 